\title{
Kebijakan Hukum Pelaksanaan Peradilan Perkara Pidana di Masa Pandemi COVID-19
}

\author{
Legal Policy for Implementing Criminal Court Justice in the COVID-19 \\ Pandemic Period
}

\author{
Nani Sriwahyuni \\ Universitas Halu Oleo \\ E-mail: naniesriwahyuni@gmail.com \\ Sabrina Hidayat \\ Pascasarjana Universitas Halu Oleo \\ E-mail: sabrina.hidayat54@yahoo.com \\ Handrawan \\ Pascasarjana Universitas Halu Oleo \\ E-mail: handrawansaranani84@gmail.com
}

\begin{abstract}
This research addressed at Analyzing the implementation of criminal justice during the COVID-19 Pandemic. Analyzing obstacles and efforts to overcome obstacles to the implementation of online criminal justice during the COVID-19 Pandemic. This paper used legal research by applying legislations, and conceptual approach. The legal approach is done by reviewing all the laws and regulations relevant to the legal issue being addressed. The conceptual approach moves away from the views or doctrines that develop in the science of law. The results showed that: 1). The implementation of justice during the COVID-19 Pandemic is carried out Virtually based on SEMA No. 1 of 2020 to prevent the spread of COVID-19 2) Virtual Court Constraints include substantive obstacles and technical obstacles. Substantial constraints: electronic trials are not mandatory, relatively closed; and the difficulty of proving. technical constraints: limited IT infrastructure and human resources; low law enforcement on IT.
\end{abstract}

Keyword: Justice; Criminal; During the COVID-19 Pandemic

Abstrak: Penelitian ini ditujukan untuk menganalisis pelaksanaan peradilan pidana di masa Pandemi COVID-19. Menganalisis kendala pelaksanaan peradilan pidana Virtual di masa Pandemi COVID-19. Jenis Penelitian ini adalah penelitian hukum normatif dengan menggunakan pendekatan undang-undang (statute approach), dan pendekatan konseptual (conceptual approach). Pendekatan undang-undang dilakukan dengan menelaah semua undang-undang dan regulasi yang bersangkut paut dengan isu hukum yang sedang ditangani. Pendekatan konseptual beranjak dari pandangan-pandangan atau doktrin-doktrin yang berkembang di dalam ilmu hukum. Hasil penelitian 
menunjukkan bahwa: 1). Pelaksanaan peradilan pidana di masa Pandemi COVID-19 dilaksanakan secara Virtual berdasarkan SEMA No. 1 Tahun 2020 guna mencegah penyebarluasan COVID-19 2) Kendala persidangan Virtual meliputi Kendala substantif dan kendala teknis. Kendala substantif: persidangan secara elektronik tidak bersifat mandatory, relatif tertutup; dan sulitnya pembuktian. kendala teknis: keterbatasan sarana-prasarana dan SDM IT; rendahnya pengetahuan aparat penegak hukum atas IT.

Kata kunci: Peradilan; Pidana; Di Masa Pandemi COVID-19

\section{PENDAHULUAN}

Pandemi COVID-19 telah menjadi salah satu kekhawatiran masyarakat karena hanya dalam kurun waktu beberapa bulan terakhir ternyata turut berdampak di berbagai aspek, salah satunya yakni penegakan hukum dalam proses sistem peradilan pidana. Dalam merespons pandemi COVID-19, negara perlu memastikan bahwa hak asasi setiap individu benar-benar dilindungi. Pandemi COVID-19 pun memaksa semua negara menata ulang sistem hukum mereka termasuk bagaimana sistem peradilan pidana beroperasi. ${ }^{1}$

Dalam rangka penegakan hukum law enforcement terdapat kehendak agar hukum tegak, sehingga nilai-nilai yang diperjuangkan melalui instrumen hukum yang bersangkutan dapat diwujudkan. Sedangkan dalam menggunakan hukum, cita-cita yang terkandung dalam hukum belum tentu secara sungguh-sungguh hendak diraih, sebab hukum tersebut digunakan untuk membenarkan tindakan-tindakan yang dilakukan to use the law to legitimate their actions. $^{2}$

Wabah Pandemi COVID-19 di tahun 2020 turut mempengaruhi sistem bersidang di pengadilan. Biasanya sidang dilakukan secara langsung dengan menghadirkan para pihak yang berperkara, namun dalam kondisi yang mewajibkan social distancing ini, maka dicarikan alternatif lain berupa pelaksanaan sidang secara elektronik. Hal ini perlu dilakukan, karena bila persidangan tetap dilaksanakan dengan pola langsung sebagaimana biasa, maka berisiko terdampak virus COVID-19, sedang bila persidangan ditunda, maka mengakibatkan kerugian bagi para terdakwa, karena nasib dan status yang belum jelas dari para Hakim.

1 Hasanal Mulkan, "Penegakan Hukum terhadap Tindakan Penyalahgunaan Kekuasaan dalam Kondisi Darurat Covid-19”, Jurnal Ilmiah Universitas Batanghari Jambi, Volume 21, No. 2, 2021, hlm. 686. Lihat juga di Fachrizal Afandi, "Penegak hukum Indonesia bertindak sewenang-wenang selama pandemi: perlunya sistem pemidanaan rasional", The Conversation, https://theconversation.com/penegak-hukumindonesia-bertindak-sewenang-wenang-selama-pandemi-perlunya-sistem-pemidanaan-rasional137604, diakses pada tanggal 13 Agustus 2021.

2 Oheo K Haris. "Telaah Yuridis Penerapan Sanksi di Bawah Minimum Khusus pada Perkara Pidana Khusus", Jurnal Ius Constituendum, Volume 2 Nomor 2 Tahun 2017, hlm. 241. 
Proses penegakan hukum pidana sebagai proses hukum yang tahapannya paling panjang dan melibatkan banyak pihak, baik warga selaku pelapor, kuasa hukum dan saksi, maupun instansi yang berkaitan. Hal ini tentu berkaitan dengan berjalannya Sistem Peradilan Pidana (Criminal Justice System) yang seharusnya berjalan dengan baikdue process of law (peradilan cepat dan adil).

Kebijakan pemerintah di masa pandemi COVID-19 dalam hal persidangan dapat dilihat dengan lahirnya Perjanjian Kerja Sama Antara Mahkamah Agung Republik Indonesia, Kejaksaan Republik Indonesia, dan Kementerian Hukum dan Hak Asasi Manusia Republik Indonesia Nomor 402/Dju/Hm.01.1/4/2020, Nomor Kep-17/E/Ejp/04/2020, Nomor Pas-08.Hh.05.05 Tahun 2020 Tentang Pelaksanaan Persidangan Melalui Teleconference (yang kemudian dalam penelitian ini disebut SKB).

Ketentuan sidang virtual pidana yang diterapkan berdasarkan Kesepakatan bersama Menteri Hukum dan HAM, Kejaksaan Agung dan Mahkamah Agung pada prinsipnya dilaksanakan guna memenuhi asas peradilan pidana cepat dan adil. Namun demikian siding virtual yang diselenggarakan dapat memunculkan potensi besar hilangnya tujuan penemuan keadilan materiel dalam perkara pidana. Sidang perkara pidana berdasarkan KUHAP adalah upaya penemuan kebenaran materiel atau kebenaran yang hakiki dari suatu peristiwa pidana dengan tujuan membuat keputusan adil masalah pidana tersebut.

Dari sudut pandang struktur sumber hukum, SKB tersebut tidak dapat mereduksi KUHAP. SKB tidak setara dengan Undang-Undang. Undang-Undang memastikan dan mewajibkan persidangan dilakukan di pengadilan dengan hadirnya terdakwa. SKB sebagai kesepakatan bersama tidak dapat mereduksi dan mengalahkan keberlakuan Undang-Undang. Sehingga menurut penulis banyak aturan-aturan yang terabaikan termasuk di dalamnya pemenuhan hak asasi manusia dalam hal memperoleh keadilan. Bukan itu saja, penerapan asasasas hukum pidana menjadi hal yang penting untuk dikaji.

Status keadaan darurat tertentu karena wabah penyakit (pandemi) corona ini tentunya memiliki dampak bagi pelaksanaan proses peradilan. Dimana "stay at home" tidak bisa dilakukan dalam pelaksanaan persidangan khusus perkara pidana karena dalam persidangan melibatkan beberapa pihak, yakni Hakim, Penuntut Umum, Penasihat Hukum, dan tentunya terdakwa dan para saksi.

Kebijakan proses peradilan pidana dalam pencegahan pandemi corona ini telah dilakukan oleh Lembaga Peradilan dimana, Kejaksaan Agung mengeluarkan surat yang ditandatangani oleh Jaksa Agung perihal Optimalisasi Pelaksanaan Tugas, Fungsi, dan 
Kewenangan di tengah Upaya Mencegah COVID-19, yang salah satu poinnya mengupayakan sidang pidana menggunakan video conference/live streaming. Dan dipertegas dengan dikeluarkan Instruksi Jaksa Agung Nomor 5 tahun 2010 Tentang Kebijakan Pelaksanaan Tugas dan Penanganan Perkara Selama Masa Pencegahan COVID-19 di Lingkungan Kejaksaan RI.

Proses Persidangan Kasus Pidana yang dilakukan secara Telekonferensi yang diselenggarakan oleh Mahkamah Agung dan Kejaksaan Agung menimbulkan banyak masalah, salah satunya upaya dalam hal pembuktian menjadi hal yang esensial dan kurang terpenuhi dengan baik.

Pemeriksaan perkara pidana di pengadilan membutuhkan ketelitian dalam memeriksa fakta yang kemudian akan ditinjau dengan penerapan hukumnya. Kalau fakta tidak bisa dicermati maka keadilan yang presisi sulit ditemukan, malah akan terjadi pengabaian pada keadilan. Sidang virtual dimana Hakim, Jaksa, dan Advokat bersama Terdakwa terpisah jarak hanya dihubungkan dengan jaringan internet yang kemudian divisualisasi dan diaudiokan melalui perangkat elektronik akan mengalami banyak hambatan; masing-masing pihak yang terpisah tidak akan dapat cermat memeriksa dokumen-dokumen yang jadi alat bukti, barang bukti, bahkan keterangan saksi berpotensi tidak akan terdengar baik, bila jaringan bermasalah. Hal ini akan membuat panitera sulit mencatat, advokat sulit mencatat dan mendokumentasikan.

\section{METODE PENELITIAN}

Penelitian ini menggunakan tipologi penelitian hukum normatif. Penelitian hukum normatif yaitu penelitian hukum sebagai norma. Penelitian hukum dilakukan untuk menghasilkan argumentasi, teori atau konsep hukum sebagai preskripsi untuk menyelesaikan masalah yang dihadapi. Dengan demikian penelitian ini mencakup analisis hukum tertulis yang didahului inventarisasi hukum positif. Hal ini akan menjadi salah satu produk analisa abstraksi dari norma hukum positif. ${ }^{3}$

Dalam melakukan penelitian ini penulis menggunakan pendekatan undang-undang (statute approach) dan pendekatan konsep (conceptual approach). Pendekatan undang-undang dilakukan dengan menelaah semua undang-undang dan regulasi yang bersangkut paut dengan isu hukum yang sedang ditangani. ${ }^{4}$ Sedangkan pendekatan konseptual, digunakan untuk memahami konsep pembaharuan hukum, dalam memahami implementasi Perma Nomor 1

3 Soentandyo Wingyosoebroto, Penelitian Hukum, Surabaya, Surabaya: Pusat Studi Hukum dan Pembangunan Fakultas Hukum Unair, 1974, hlm 1,7-8

4 Peter Mahmud Marzuki, Penelitian Hukum, edisi revisi cetakan Ke-13, Jakarta: Kencana, 2017, hlm. 133. 
Tahun 2020; sehingga diharapkan penormaan dalam aturan hukum dalam mengkaji serta menganalisis kerangka pikir atau kerangka konseptual maupun landasan teoritis sesuai dengan tujuan penelitian ini.

\section{ANALISIS DAN PEMBAHASAN}

\section{Pelaksanaan Peradilan Perkara Pidana Di Masa Pandemi Covid-19}

\section{Sistem Peradilan Pidana Virtual}

Sidang Virtual adalah suatu terobosan untuk tetap dapat terselenggaranya persidangan dengan cepat dan berbiaya murah. Sidang virtual perlu untuk tetap di laksanakan tidak hanya dalam masa pandemi tetapi juga untuk kondisi-kondisi yang lain misalnya saksi yang tidak dapat hadir di persidangan

Pandemi Virus Corona membuat kegiatan apa pun serba terbatasi. Termasuk dalam kerja-kerja pemberantasan korupsi. Ini karena pemerintah tengah menerapkan physicial distancing (jaga jarak) guna meminimalisasi penyebaran virus tersebut. Bagi persidangan perkara pidana, munculnya wabah COVID-19 di awal tahun 2020 memang sempat menimbulkan kepanikan di kalangan para penegak hukum saat itu belum tersedia payung hukum bagi pelaksanaan persidangan pidana secara elektronik. Agar persidangan kasus korupsi tetap berjalan, Mahkamah Agung pun mengeluarkan Surat Edaran Nomor 1 Tahun 2020 Tentang Pedoman Pelaksanaan Tugas Selama Masa Pencegahan Penyebaran Coronavirus Disease (COVID-19), di Lingkungan Mahkamah Agung dan Badan Peradilan yang Berada di Bawahnya. Perjanjian Kerja Sama tertanggal 13 April 2020 antara Mahkamah Agung Republik Indonesia Nomor: 402/DJU/HM.01.1/4/2020, Kejaksaan Agung Republik Indonesia Nomor: KEP-17/E/Ejp/04/2020 dan Kementerian Hukum dan Hak Asasi Manusia Republik Indonesia Nomor:PAS-08.HH.05.05 Tahun 2020 tentang Pelaksanaan Persidangan melalui Teleconference.

Dalam surat edaran tersebut, pihak MA memperbolehkan proses persidangan dilakukan secara virtual (virtual), guna menekan penyebaran virus. Para penegak hukum seperti jaksa dan pengacara pun berkreasi menghadirkan saksi secara virtual melalui aplikasi dan jaringan internet. Terdakwa sendiri bisa mengikuti sidang perkara yang melilitnya dari dalam Rutan, sementara jaksa atau pengacara pun bisa mengikuti jalannya sidang dari kantor atau rumah masing-masing. PERMA Nomor 4 Tahun 2020 lebih memberikan payung hukum tentang persidangan yang dilakukan secara elektronik terhadap perkara pidana Mantan wakil ketua Pengadilan Negeri Malang ini membeberkan, selepas PERMA Nomor 4 Nomor 2020 diundangkan maka MA dan badan peradilan di bawahnya melakukan sosialisasi. 
PERMA ini pada dasarnya juga mendukung bagi upaya pencegahan penyebaran COVID19 di lingkungan peradilan Dia mengungkapkan, pelaksanaan persidangan virtual memang masih banyak kendala. Tapi, MA dan badan peradilan di bawahnya serta pihak terkait pasti akan berusaha semaksimal mungkin. Dia menjelaskan, hakikatnya persidangan setiap terdakwa, saksi, ataupun ahli dihadapkan di persidangan dalam keadaan bebas. Penghadapan itu juga berlaku saat persidangan virtual. Karenanya saat persidangan virtual, kamera yang dipakai dapat menunjukkan keadaan sekitar para pihak.

PERMA mencantumkan ruang sidang elektronik yakni ruang sidang di pengadilan yang meliputi kantor Kejaksaan, kantor Rutan/Lapas, atau tempat lain yang ditetapkan majelis hakim. PERMA juga memasukkan ketentuan domisili elektronik dan dokumen elektronik. Domisili elektronik adalah layanan pesan berupa akun yang terverifikasi milik penyidik, penuntut, pengadilan, terdakwa/kesatuan terdakwa, penasihat hukum, saksi, ahli, Rutan, dan Lapas.

Dokumen elektronik yakni dokumen administrasi terkait perkara dan persidangan yang diterima, disimpan, dan dikelola di Sistem Informasi Pengadilan. Setiap dokumen elektronik yang disampaikan oleh Jaksa Penuntut Umum (JPU), penasihat hukum, dan terdakwa harus berbentuk PDF. Setiap dokumen elektronik yang dikirim harus diunduh dan diverifikasi antara yang dibacakan dengan yang diunduh. Persidangan secara elektronik adalah serangkaian proses memeriksa, mengadili, dan memutus perkara terdakwa oleh pengadilan yang dilaksanakan dengan dukungan teknologi informasi dan komunikasi, audio visual, dan sarana elektronik lainnya ${ }^{5}$.

Proses persidangan secara elektronik dapat dilakukan dalam empat kondisi sebagaimana Pasal 2 ayat (2). Pertama, hakim/majelis hakim, panitera/panitera pengganti, dan JPU bersidang di ruang sidang pengadilan, sementara terdakwa mengikuti persidangan dari tempatnya ditahan (Rutan/Lapas) dengan didampingi/tanpa didampingi penasihat hukum. Kedua, hakim/majelis hakim dan panitera/panitera pengganti bersidang di ruang sidang pengadilan, sementara JPU mengikuti persidangan dari kantor JPU, dan terdakwa mengikuti persidangan dengan didampingi/tanpa didampingi penasihat hukum dari Rutan/Lapas tempat terdakwa ditahan.

5 Pasal 1 angka 12 Peraturan Mahkamah Agung Nomor 4 Tahun 2020 tentang Administrasi dan Persidangan Perkara Pidana di Pengadilan Secara Elektronik. Lihat dalam Panji Purnama dan Febby Mutiara Nelson, "Penerapan E-Court Perkara Pidana Sebagai Salah Satu Upaya Terwujudnya Integrated Judiciary dalam Sistem Peradilan Pidana di Indonesia”, Jurnal RechtsVinding, Volume 10 Nomor 1, April 2021, hlm. 100. 


\section{Dasar Pertimbangan Hakim dalam Memutus Perkara pada Proses Peradilan Pidana yang}

\section{Digelar Selama Masa Pandemi}

Pertimbangan hakim adalah salah satu aspek yang sangat penting untuk mewujudkan nilai dari suatu putusan hakim yang mengandung keadilan (ex aequo et bono) dan mengandung kepastian hukum, di samping itu terdapat juga manfaat bagi para pihak yang bersangkutan sehingga pertimbangan hakim ini harus disikapi dengan teliti, baik, dan cermat. Jika pertimbangan hakim tidak teliti, baik, dan cermat, maka putusan hakim yang berasal dari pertimbangan hakim tersebut akan dibatalkan oleh Pengadilan Tinggi/Mahkamah Agung. ${ }^{6}$

Dalam pemeriksaan perkara hakim harus memperhatikan terkait pembuktian, karena hasil dari pembuktian tersebut nantinya akan digunakan sebagai bahan pertimbangan untuk memutus perkara. Pembuktian adalah tahap yang sangat penting dalam pemeriksaan di persidangan. Tujuan pembuktian adalah untuk memperoleh kepastian bahwa suatu peristiwa/fakta yang diajukan itu benar-benar terjadi, guna mendapatkan putusan hakim yang benar dan adil. Hakim tidak akan bisa menjatuhkan suatu putusan sebelum nyata baginya bahwa peristiwa/fakta tersebut benar-benar terjadi, yakni dibuktikan kebenarannya, sehingga tampak adanya hubungan hukum antara para pihak ${ }^{7}$

Putusan hakim sangat berkaitan dengan bagaimana hakim dalam mengemukakan pendapat atau pertimbangannya berdasarkan fakta-fakta serta alat bukti di persidangan serta keyakinan hakim atas suatu perkara. Oleh sebab itu hakim memiliki peran sentral dalam menjatuhkan putusan pengadilan. Di dalam putusan pengadilan harus terdapat pertimbanganpertimbangan mengenai hal-hal yang memberatkan dan meringankan putusan, pertimbangan tersebut dijadikan alasan oleh hakim dalam menjatuhkan putusannya baik itu berupa putusan pemidanaan yang lain sebagainya. ${ }^{8}$

Pertimbangan mengenai hal-hal yang memberatkan dan meringankan terdakwa ini diatur dalam Pasal 197 huruf d dan 197 huruf f KUHAP dalam Pasal 197 huruf d berbunyi "Pertimbangan yang disusun secara ringkas mengenai fakta dan keadaan beserta alat pembuktian yang diperoleh dari pemeriksaan disidang yang menjadi dasar penentuan

6 Mukti Aro, Praktik Perkara Perdata pada Pengadilan Agama. cet V. Yogyakarta: Pustaka Pelajar. hlm. 140.

7 Ibid., hlm. 141

8 Nurhafifah dan Rahmiati. "Pertimbangan Hakim Dalam Penjatuhan Pidana Terkait Hal Yang Memberatkan dan Meringankan Putusan”. Jurnal Ilmu Hukum Fakultas Hukum Unsyiah, No. 66, 2015, hlm. 344 . 
kesalahan terdakwa". Sedangkan Pasal 197 huruf f berbunyi "Pasal peraturan perundangundangan yang menjadi dasar pemidanaan atau tindakan dan peraturan perundang-undangan yang menjadi dasar hukum dari putusan, disertai keadaan yang memberatkan dan meringankan terdakwa Sebagai penegak hukum, hakim mempunyai tugas dibidang yudisial, yaitu menerima, memeriksa, memutuskan dan menyelesaikan setiap perkara yang diajukan kepadanya. Para pencari keadilan tentu sangat mendambakan perkara-perkara yang diajukan ke pengadilan dapat diputus oleh hakim yang profesional dan memiliki integritas moral yang tinggi, sehingga dapat melahirkan keputusan-keputusan yang sesuai dengan aturan perundang-undangan

Ada beberapa faktor yang mempengaruhi hakim dalam membuat putusannya, dibagi menjadi faktor subjektif dan faktor objektif. Faktor subjektif meliputi:

a. Sikap perilaku apriori, yakni adanya sikap hakim yang sejak semula sudah menganggap bahwa terdakwa yang diperiksa dan diadili adalah orang yang memang bersalah dan harus dipidana.

b. Sikap perilaku emosional, yakni putusan pengadilan akan dipengaruhi oleh perangai hakim. Hakim yang mempunyai perangai mudah tersinggung akan berbeda dengan perangai hakim yang tidak mudah tersinggung.

c. Sikap arrogance power, yakni sikap lain yang mempengaruhi suatu putusan adalah "kecongkakkan kekuasaan", di sini hakim merasa dirinya berkuasa dan pintar, melebihi orang lain (jaksa, pembela, ataupun terdakwa).

d. Moral, yakni moral seorang hakim karena bagaimanapun juga pribadi seorang hakim diliputi oleh tingkah laku yang didasari oleh moral pribadi hakim tersebut dalam memeriksa serta memutuskan suatu perkara. ${ }^{9}$

Faktor objektif meliputi:

a. Latar belakang budaya, yakni kebudayaan, agama, pendidikan seseorang tentu ikut mempengaruhi putusan hakim. Meskipun latar belakang hidup budaya tidak bersifat determinis, tetapi faktor ini setidaknya ikut mempengaruhi hakim dalam mengambil suatu keputusan.

b. Profesionalisme, yakni kecerdasan serta profesionalisme seorang hakim ikut mempengaruhi putusannya. Perbedaan suatu putusan sering dipengaruhi oleh

9 Yahya Harahap, sebagaimana dikutip M. Syamsudin, Konstruksi Baru Budaya Hukum Hakim Berbasis Hukum Progresif. Jakarta: Kencana. 2012, hlm. 93. 
profesionalisme hakim tersebut. ${ }^{10}$

Hakim dalam mengadili pelaku tindak pidana harus melalui proses penyajian kebenaran dan keadilan dalam suatu putusan pengadilan sebagai rangkaian proses penegakan hukum. Dalam menjatuhkan putusan hakim harus memiliki dasar pertimbangan yang didasarkan pada keyakinan serta didukung oleh adanya alat-alat bukti yang sah sehingga putusan yang dijatuhkan hakim benar-benar memenuhi rasa keadilan masyarakat. Hakim dalam menjatuhkan putusan harus mempertimbangkan banyak hal, baik itu yang berkaitan dengan perkara yang sedang diperiksa, tingkat perbuatan dan kesalahan yang dilakukan pelaku, kepentingan pihak korban, keluarganya dan rasa keadilan. ${ }^{11}$

Proses penyelesaian perkara pidana, putusan hakim selalu didasari pada surat pelimpahan perkara yang memuat seluruh dakwaan atas kesalahan terdakwa. Selain itu, putusan hakim juga tidak boleh terlepas dari fakta persidangan atau proses pembuktian selama masa persidangan. Peran hakim dalam mengadili suatu perkara pidana sangat penting ketika putusan atau vonis telah dibuat atau dibacakan. Putusan hakim sangat menentukan nilai suatu kebenaran dan menentukan salah atau tidaknya suatu perbuatan yang dilakukan oleh seseorang. ${ }^{12}$

Menurut Pasal 1 Undang-Undang Nomor 8 Tahun 1981 tentang KUHAP, bahwa hakim adalah pejabat peradilan negara yang diberi wewenang oleh undang-undang untuk mengadili. Kata "mengadili" sebagai rangkaian tindakan hakim untuk menerima, memeriksa, dan memutus perkara berdasarkan asas bebas, jujur, dan tidak memihak dalam sidang perkara pidana. Hakim sebagai orang yang menegakkan hukum demi keadilan ketika hendak menjatuhkan putusan tetap berlandaskan pada aturan yang berlaku dalam undang-undang dan memakai pertimbangan berdasarkan alat bukti yang sah serta para saksi yang telah disumpah di depan persidangan. ${ }^{13}$

Alat bukti yang dipergunakan sebagai bahan pertimbangan hakim, menurut KUHAP adalah alat-alat bukti yang sah. Alat bukti tersebut berupa keterangan ahli, surat, petunjuk dan

10 LH Permana, Analisis Pertimbangan Hukum Hakim dalam Penjatuhan Pidana di Bawah Minimum Terhadap Pelaku Tindak Pidana Kesusilaan. Jurnal. Fakultas Hukum Universitas Lampung, 2016, hlm. 9.

11 Rachmad Afandi, "Analisis Dasar Pertimbangan Hukum Hakim dalam Menjatuhkan Pidana Terhadap Pelaku Pencabulan Terhadap Anak (Studi Putusan Nomor: 66/Pid/2013/PT.TK)", Jurnal Poenale, Vol 3, No 4, 2015, hlm. 4.

12 Faisal Riza, "Keyakinan Hakim dalam Memutus Perkara Pidana", Litigasi, https://www.litigasi.co.id/ posts/keyakinan-hakim-dalam-memutus-perkara-pidana Litigasi, diakses pada tanggal 19 Agustus 2021.

13 Ibid. 
keterangan terdakwa, hal ini bertujuan untuk mendapatkan keyakinan hakim bahwa suatu tindak pidana telah terjadi dan terdakwalah yang bersalah melakukannya. ${ }^{14}$

Keterangan saksi dalam persidangan juga dapat mempengaruhi keyakinan hakim dalam mempertimbangkan bukti-bukti yang ada. Apabila keterangan yang diberikan saksi dalam persidangan "dibuat-buat" menurut terkaan atau pemikiran saja, atau keterangan bukan berdasarkan fakta atau keahlian, maka hakim boleh untuk tidak mempertimbangkannya. ${ }^{15}$

Hakim dalam memutus suatu perkara tidak hanya berdasarkan bukti-bukti yang ada, tetapi penting juga didasarkan oleh keyakinan sebagai seorang hakim dalam memutus perkara. ${ }^{16}$

Seperti diungkapkan oleh Anselmus A.R. Masiku salah satu Pengacara di Kota Kendari, ketika harus memeriksa barang bukti berupa sabu. Sabu itu kan seperti butiran dan mirip gula. Nah kalau tidak dilihat langsung tidak bisa membedakan. Kemudian kepastian barang bukti, warna, ukuran, apakah ada noda bercak darah atau yang lain itu harus dibuktikan. Mereka (terdakwa kasus pidana) karena dalam sidang sudah dianggap salah. Hakim pun tidak cermat lagi memeriksa.

Di situlah hakim harusnya tetap melihat kepentingan terdakwa sebelum memutuskan membebani terdakwa dengan pemberatan hukum. Hak memeroleh kejelasan komunikasi langsung, kebebasan berekspresi menanggapi pernyataan saksi jauh lebih esensial. Ada kerugian-kerugian besar yang dialami peradilan lewat sidang virtual. Intinya banyak kehilangan momentum karena persidangan ditentukan oleh bagus tidaknya alat komunikasi Zoom.

Prinsipnya peradilan wajib dihadiri terdakwa. Jika tidak dihadiri terdakwa, tidak sah. Hanya peradilan korupsi dan TPPU saja yang boleh dilaksanakan secara inabsentia, dengan alasan penyelamatan uang negara. Bagi tindak pidana lain, termasuk kerumunan wajib dihadirkan terdakwanya, jika tidak sidangnya tidak sah. Lagi pula, di luar pertimbanganpertimbangan hakim, kita harus melihat landasan hukum yang lebih mengakar, soal penyelenggaraan sidang virtual yang sebenarnya didasari Surat Edaran MA. Sementara, dasar penyelenggaraan sidang terbuka adalah perintah UU di KUHAP. 
Jadi seharusnya dengan menerapkan protokol COVID-19 dengan ketat, persidangan tetap harus diselenggarakan secara langsung dan terbuka dengan menghadirkan terdakwa secara langsung sesuai dengan ketentuan-ketentuan hukum acara di KUHAP.

\section{Kendala Pelaksanaan Sidang Virtual di Masa Pandemi COVID-19}

\section{Kendala Sidang Virtual}

Terdapat sejumlah kendala dalam pelaksanaan sidang secara virtual. Keluhan pertama adalah kualitas Internet yang kurang baik sehingga menyebabkan proses sidang berjalan tidak sebagaimana mestinya. Di samping itu kurang memadainya peralatan pendukung untuk pelaksanaan sidang secara virtual. Layar monitor, mikrofon, proyektor, kamera, dan pengeras suaranya belum tersedia di semua ruang sidang.

Kemudian hanya satu layar yang tersedia dalam ruang sidang sehingga penasihat hukum dan jaksa kadang tidak dapat melihat pihak lain dengan jelas. Lalu penasihat hukum harus duduk bersebelahan dengan jaksa dan saksi agar dapat bergiliran menggunakan mikrofon dan terekam kamera.

Masalah lainnya adalah keterbatasan sumber daya manusia di bidang teknologi informasi. Tidak semua pengadilan negeri, kejaksaan negeri, dan lembaga pemasyarakatan atau rumah tahanan memiliki staf teknologi informasi. Sehingga bila terjadi kendala teknis di tengah persidangan, maka kemudian yang terjadi adalah kesulitan untuk mengatasi, sementara proses persidangan berjalan terus. Yang berikutnya adalah keterbatasan penguasaan teknologi oleh sebagian hakim.

Persoalan lain adalah beberapa pengadilan negeri hanya berkoordinasi dengan kejaksaan tanpa melibatkan penasihat hukum dan pihak lembaga pemasyarakatan atau rumah tahanan. Alhasil, penasihat hukum tidak mendapatkan informasi mengenai proses persidangan yang akan dilakukan.

Dalam sidang secara virtual, penasihat hukum tidak bisa berada di dekat terdakwa karena terdakwa harus tetap berada di lembaga pemasyarakatan atau rumah tahanan. Sehingga mengurangi kualitas pendampingan terhadap terdakwa. ${ }^{17}$

Kendala lainnya adalah proses sidang di daerah kerap terputus karena menggunakan aplikasi Zoom yang gratis dan waktunya memang dibatasi selama 40 menit. Para penasihat

17 Warga Binaan Pemasyarakatan Lapas Perempuan Kelas III Kendari. Wawancara tanggal 21 April 2021. 
hukum tidak dapat memastikan saksi maupun terdakwa tidak dalam posisi tekanan atau berdusta ketika memberikan keterangan pada saat persidangan. Karena persidangan secara virtual ini membuat para pihak bebas berada di mana pun, tidak di dalam satu ruangan sidang. Sehingga para penasihat hukum meragukan kebebasan saksi ketika memberikan keterangan. ${ }^{18}$

\section{Upaya Mengatasi Kendala Pelaksanaan Sidang Peradilan Pidana secara Virtual}

Di Indonesia, aturan mengenai persidangan virtual telah diatur dalam PERMA No. 1 Tahun 2019 tentang Administrasi Perkara dan Persidangan di Pengadilan secara Elektronik. PERMA ini mengatur pada lingkup Pengadilan Negeri, Pengadilan Agama atau Mahkamah Syariah, Pengadilan Militer dan Pengadilan Tata Usaha Negara. Administrasi perkara dan persidangan di pengadilan secara elektronik meliputi proses penerimaan gugatan, penyampaian panggilan atau pemberitahuan siding, permohonan nota keberatan (eksepsi), bantahan, perlawanan, intervensi, jawaban, replik, duplik, kesimpulan, penerimaan pembayaran penerimaan upaya hukum, pengelolaan, penyampaian, penyimpanan dokumen perdata/perdata Agama/tata usaha Militer/tata usaha Negara.

Kemudian juga, dijelaskan terkait persidangan elektronik itu sendiri yaitu serangkaian proses memeriksa dan mengadili perkara oleh pengadilan yang dilaksanakan dengan dukungan teknologi informasi dan komunikasi sebagaimana tercantum Pasal 1 angka 7 PERMA No. 1 Tahun 2009 tentang Administrasi Perkara dan Persidangan di Pengadilan secara Elektronik.

Mahkamah Agung sudah mempunyai terobosan sejak dua tahun lalu untuk perkara perdata, perdata agama, tata usaha militer dan tata usaha negara yang memanfaatkan teknologi untuk persidangan. Untuk pencari keadilan dengan perkara jenis itu, gedung pengadilan bukan satu-satunya yang harus dituju, melainkan dapat juga mengakses aplikasi peradilan elektronik atau e-Court. Bahkan yang terbaru, Mahkamah Agung telah menambahkan fitur untuk upaya banding.

Mengikuti terobosan untuk bidang administratif itu, Mahkamah Agung setahun kemudian meluncurkan e-Litigasi yang pertama diberlakukan untuk lingkungan peradilan umum, agama dan tata usaha negara. Perma itu mengatur ruang sidang secara elektronik adalah ruang sidang di pengadilan yang meliputi kantor kejaksaan, Rutan/Lapas atau tempat lain yang ditetapkan oleh majelis hakim dengan ketentuan semua peserta sidang harus terlihat di layar monitor dengan terang dan suara yang jelas.

18 Hasruddin. Advokat Posbakum ADIN Sulawesi Tengggara. Wawancara tanggal 2 Mei 2021. 
Untuk mengikuti persidangan daring, penyidik, penuntut, pengadilan, terdakwa, penasihat hukum, saksi, ahli Rutan dan Lapas harus memiliki akun yang terverifikasi. Sementara dokumen administrasi pun disampaikan secara elektronik dengan disimpan dan dikelola sistem informasi pengadilan.

Meski hakim tidak secara langsung bertatap muka dengan terdakwa, saksi mau pun ahli, keterangan yang diberikan pihak-pihak itu dalam persidangan elektronik ditegaskan mempunyai nilai pembuktian yang sama.

Ada pun keadaan yang memungkinkan dilakukannya persidangan daring antara lain terjadi bencana alam, wabah penyakit, keadaan yang ditetapkan pemerintah sebagai keadaan darurat atau keadaan lain yang menurut majelis hakim dengan penetapan perlu persidangan secara elektronik.

Sementara untuk teknis sidang, Perma mengatur pemanggilan persidangan sepekan sebelum sidang disampaikan ke domisili elektronik melalui pos elektronik, aplikasi perpesanan atau pesan singkat. Domisili elektronik adalah domisili para pihak berupa alamat surat elektronik dan/atau nomor telepon seluler yang telah terverifikasi.

Kemudian ruang terdakwa dalam mengikuti persidangan hanya boleh dihadiri terdakwa, penasihat hukum, petugas Rutan/Lapas dan petugas IT. Sementara saksi dan ahli dapat diperiksa di kantor penuntut, pengadilan atau kedutaan/konsulat apabila berada di luar negeri. Khusus untuk saksi yang identitasnya menurut peraturan perundang-undangan wajib dirahasiakan, keterangan dapat disampaikan dalam format audio yang disamarkan suaranya atau pemberian keterangan tanpa dihadiri terdakwa.

Selanjutnya untuk pemeriksaan barang bukti pun dilakukan secara daring karena tetap berada di kantor penuntut umum, kecuali dokumen cetak yang dapat dipindai. Sedangkan untuk barang bukti selain dokumen cetak, majelis hakim menerima foto atau video dari barang bukti.

Untuk tuntutan pidana, pembelaan, replik dan duplik dibacakan di muka sidang sesuai ketentuan hukum acara. Begitu juga dengan putusan yang dibacakan secara elektronik.

\section{KESIMPULAN}

Pelaksanaan peradilan pidana di masa Pandemi COVID-19 dilaksanakan secara Virtual berdasarkan PERMA Nomor 1 Tahun 2020, hampir di seluruh Pengadilan dengan beberapa situasi tergantung situasi dan kondisi jaringan internet. Kendala pelaksanaan peradilan pidana virtual di masa Pandemi COVID-19 meliputi Tenaga IT yang terbatas menyebabkan persiapan persidangan virtual menjadi lamban, terlebih jika terdapat kendala teknis di tengah 
persidangan. Belum ada keseragaman dari Pengadilan untuk sidang secara telekonferensi dengan tetap meminta kehadiran Penuntut Umum dan Penasihat Hukum Terdakwa serta saksi di persidangan. Isu keamanan terkait penggunaan aplikasi telekonferensi. Keberatan dari PH untuk sidang secara telekonferensi. Belum stabilnya jaringan internet, sehingga sering terjadi delay dan terputusnya jaringan pada saat persidangan. Asas terbuka untuk umum

\section{Daftar Pustaka}

\section{Buku}

Aro, Mukti, Praktik Perkara Perdata pada Pengadilan Agama. cet V. Yogyakarta: Pustaka Pelajar. Marzuki, Peter Mahmud, Penelitian Hukum, edisi revisi cetakan Ke-13, Jakarta: Kencana, 2017. Permana, LH, Analisis Pertimbangan Hukum Hakim dalam Penjatuhan Pidana di Bawah Minimum Terhadap Pelaku Tindak Pidana Kesusilaan. Jurnal. Fakultas Hukum Universitas Lampung, 2016.

Syamsudin, M., Konstruksi Baru Budaya Hukum Hakim Berbasis Hukum Progresif. Jakarta: Kencana. 2012.

Wingyosoebroto, Soentandyo, Penelitian Hukum, Surabaya, Surabaya: Pusat Studi Hukum dan Pembangunan Fakultas Hukum Unair, 1974.

\section{Jurnal dan Makalah}

Afandi, Rachmad, "Analisis Dasar Pertimbangan Hukum Hakim dalam Menjatuhkan Pidana Terhadap Pelaku Pencabulan Terhadap Anak (Studi Putusan Nomor: 66/Pid/2013/PT.TK)”, Jurnal Poenale, Vol 3, No 4, 2015.

Haris, Oheo K. "Telaah Yuridis Penerapan Sanksi di Bawah Minimum Khusus pada Perkara Pidana Khusus", Jurnal Ius Constituendum, Volume 2 Nomor 2 Tahun 2017.

Mulkan, Hasanal, “Penegakan Hukum terhadap Tindakan Penyalahgunaan Kekuasaan dalam Kondisi Darurat Covid-19”, Jurnal Ilmiah Universitas Batanghari Jambi, Volume 21, No. 2 , 2021.

Nurhafifah dan Rahmiati. "Pertimbangan Hakim Dalam Penjatuhan Pidana Terkait Hal Yang Memberatkan dan Meringankan Putusan". Jurnal Ilmu Hukum Fakultas Hukum Unsyiah, No. 66, 2015.

Purnama, Panji dan Febby Mutiara Nelson, "Penerapan E-Court Perkara Pidana Sebagai Salah Satu Upaya Terwujudnya Integrated Judiciary dalam Sistem Peradilan Pidana di Indonesia", Jurnal RechtsVinding, Volume 10 Nomor 1, April 2021. 


\section{Peraturan Perundang-undangan}

Undang-Undang Dasar Negara Republik Indonesia Tahun 1945

Undang-Undang Nomor 8 Tahun 1981 tentang Hukum Acara Pidana.

Peraturan Mahkamah Agung Republik Indonesia Nomor 1 Tahun 2019 tentang Administrasi Perkara dan Persidangan Secara Elektronik

Peraturan Mahkamah Agung Nomor 4 Tahun 2020 tentang Administrasi dan Persidangan Perkara Pidana di Pengadilan Secara Elektronik

Surat Edaran Mahkamah Agung Nomor 1 Tahun 2020 Penyesuaian Sistem Kerja Hakim dan Aparatur Peradilan dalam Upaya Pencegahan Penyebaran COVID-19 di Lingkungan Mahkamah Agung RI dan Badan Peradilan di Bawahnya

Instruksi Jaksa Agung Nomor 5 tahun 2010 Tentang Kebijakan Pelaksanaan Tugas dan Penanganan Perkara Selama Masa Pencegahan COVID-19 di Lingkungan Kejaksaan RI

\section{Situs Web}

Afandi, Fachrizal, "Penegak hukum Indonesia bertindak sewenang-wenang selama pandemi: perlunya sistem pemidanaan rasional", The Conversation, https://theconversation.com/penegak-hukum-indonesia-bertindak-sewenangwenang-selama-pandemi-perlunya-sistem-pemidanaan-rasional-137604, diakses pada tanggal 13 Agustus 2021.

Riza, Faisal, "Keyakinan Hakim dalam Memutus Perkara Pidana", Litigasi, https://www.litigasi.co.id/ posts/keyakinan-hakim-dalam-memutus-perkara-pidana Litigasi, diakses pada tanggal 19 Agustus 2021. 